\title{
Virtual exchange for internationalisation at home in China: staff perspectives
}

\section{Sara Ganassin'1, Müge Satar², and Ashleigh Regan³}

\section{Abstract}

D

espite the central role of internationalisation strategies in the agendas of universities all over the world - with BRIC countries (Brazil, Russia, India, and China) emerging as powerful regional stakeholders - very few studies have investigated how internationalisation is interpreted and operationalised in non-Western contexts. We offer an exploration of Internationalisation at Home (IaH) (Robson, Almeida, \& Schartner, 2018) in the context of Chinese Higher Education (HE) with a focus on the perceptions of staff. This qualitative study investigates how 15 teachers and administrators understand the practice of Virtual Exchange (VE) within their institution's IaH agenda. Findings show that participants think that VE could contribute to internationalisation and provide an inclusive way of accessing international and intercultural experiences. VE has the potential to enhance internationalisation and global engagement of Chinese HE Institutions (HEIs). At the same time, its implementation presents challenges that require careful consideration and planning. These include means for establishing partnerships with a mutual understanding of realities, unique power dynamics among learner groups, and techno-political challenges.

Keywords: internationalisation at home; virtual exchange; Chinese higher education; intercultural competence.

1. Newcastle University, United Kingdom; sara.ganassin@newcastle.ac.uk; https://orcid.org/0000-0002-0373-542X

2. Newcastle University, United Kingdom; muge.satar@newcastle.ac.uk; https://orcid.org/0000-0002-2382-6740

3. Newcastle University, United Kingdom; a.regan@newcastle.ac.uk; https://orcid.org/0000-0001-7404-0572

How to cite this article: Ganassin, S., Satar, M., \& Regan, A. (2021). Virtual exchange for internationalisation at home in China: staff perspectives. Journal of Virtual Exchange, 4(SI-IVEC2020), 95-116. https://doi.org/10.21827/jve.4.37934 


\section{Introduction}

Internationalisation of $\mathrm{HE}$ is the process of integrating an international, intercultural, or global dimension into HE (Knight, 2004). Internationalisation plays a central role in the agenda of universities all over the world with BRIC countries emerging as powerful regional stakeholders (Wihlborg \& Robson, 2017). Yet very few studies have investigated how internationalisation is interpreted and implemented in non-Western contexts and the role of VE in this process. Despite the increasing number of Chinese students and staff able to study and work abroad, for various reasons such as caring duties and financial restrictions, many are still not afforded such opportunities. We report on a transnational (UK and People's Republic of China) project on IaH in the context of Chinese HE to offer a conceptualisation, grounded in empirical data, of how the physically non-mobile majority of staff (teachers and administrators) understand and experience internationalisation and VE.

The European Union has already made some progress in identifying the core dimensions of IaH (see ATIAH, 2018). However, the research community in China has not been as prolific. In China, internationalisation is primarily seen and implemented in terms of international physical mobility of staff and students, joint international degrees, curricular adaptations, and collaborative research (Chun, 2014; Wang, 2018; Yang, 2014; Zha, Wu, \& Hayhoe, 2019). Few studies have examined how the non-mobile majority of students and staff understand and experience internationalisation (e.g. De Wit, 2016; O’Dowd, 2021). To address this gap, we explored how 15 HE staff, with various teaching and leadership roles at one Chinese university, understand IaH and the practice of VE. We address the following research questions.

- How do teachers and administrators at a university in China understand IaH?

- What role can VE play in the process of IaH within this institutional context?

- What are the opportunities and challenges in VE implementation for IaH?

The key contribution of this research is twofold. First, we address a strategic area that is considered highly relevant within the Chinese HE system: enhancing the quality of IaH. Second, we offer some recommendations for researchers, institutions, and VE practitioners who are interested in developing collaborative work with China.

\section{Background}

This study was informed by concepts of internationalisation, particularly IaH and by VE theory and practice. 


\subsection{Internationalisation of Chinese $\mathrm{HE}$}

Internationalisation is a key area for education and intercultural communication research since successful internationalisation can contribute to the quality and relevance of HE (Young, Handford, \& Schartner, 2017). This is particularly relevant in the Chinese context where internationalisation has become an important part of the HE system, with many universities readily welcoming such processes (Zha et al., 2019). Accordingly, in China, internationalisation is both well-defined in terms of aims and objectives, and incentivised by the state, which, in turn, has played an important role in improving the quality of HE (Zha et al., 2019).

In 2015, the State Council of the People's Republic of China (PRC) launched the Double FirstClass Initiative (DFCI) to accelerate the internationalisation of HE and enhance the international influence and competitiveness of China (Zhao, 2018). Research pertaining to the DFCI has argued that there has been a shift towards "institutionalisation, decentralisation, and expanded participation" in policymaking, compared to the 985 Project which was implemented in the 1990's (Zhao, 2018, p. 6). However, it has been suggested that this claim is oversimplified, since while evidence shows financial support has been largely decentralised, there is little participation from actors independent of the government or education system in the decision making process (Zhao, 2018). In this way, researchers have suggested that the current processes of internationalisation serve to assimilate Chinese universities to Western practices, leaving little room for innovation on the meso and micro level (Zha et al., 2019). Current literature has explored the macro-level of internationalisation through the large lens of national policies and governance (Liu, Turner, \& Jing, 2019; Zhao, 2018). Although it has been noted that efforts to create world-class universities have an impact on individuals too, through practices such as reform and modification of management, staffing, recruitment, and collaboration (Liu, Wang, \& Cheng, 2011, as cited in Song, 2018), little is actually known about the experiences of the individual Chinese universities (strategic dimension) and of their staff and students (individual dimension). Here, we focus on the individual dimension and particularly on the perceptions of university staff with teaching and leadership roles (teachers and administrators).

\subsection{Intercultural communication and internationalisation of Chinese HE}

Intercultural communication has developed rapidly in China against the backdrop of globalisation and internationalisation since the 1980's. As a result, China's Ministry of Education (MOE) has issued several policy documents to urge the integration of intercultural communication and Intercultural Competence (IC) into HE (National Foreign Language Teaching Advisory Board, 2018; Sun, Liao, Zheng, \& Qin, 2021). 
In the context of Chinese HE, enhancing opportunities for global engagement of faculty and students aligns with the goals and needs of HEIs and national strategic development. At the same time, it generates high demand for special preparation for the students and faculty (MOE, 2018), which is of key importance to successful IaH. Accordingly, practices that foster global, international, and intercultural learning can play an important role in equipping students to thrive in their increasingly international realities (Krebs, 2020).

Elements of internationalisation, specifically IaH, feature in the State Council's (2019) Modernisation of Education 2035 plan, which includes aims such as enhancing exchange and cooperation, and fostering a mutual learning environment on an international level. Wang (2018) found that at a university in China, IaH is one of the three key internationalisation strategies, in addition to "curriculum internationalisation" and "intercultural dialogue" (p. i). These strategies were found to strongly contribute to students' IC, providing further emphasis on its importance. The concept of IC, to which we will return in our discussion, refers to 'the appropriate and effective management of interaction between people who, to some degree or another, represent different or divergent affective, cognitive, and behavioral orientations to the world' (Spitzberg \& Changnon, 2009, p. 7). IC intends that people understand and respect individuals whom we perceive to have different cultural affiliations; respond appropriately, effectively, and respectfully; and "establish positive and constructive relationships..., understand [themselves and their own] multiple cultural affiliations through encounters with cultural 'difference”' (Barrett et al., 2013, p. 16). Holmes and O'Neill (2012) draw on Kramsch's (1998) concept of 'third space' to argue that IC is most easily observed in intercultural encounters, spaces where people from different cultural, national, and social backgrounds negotiate cultural and social identifications and self-representations. VE has been extensively studied for its affordances for IC development, which is explored in more detail in the next section.

\title{
2.3. VE for IC development, as part of IaH, and in the global East
}

We draw on the definition of VE offered by O'Dowd (2020):

\begin{abstract}
"Virtual exchange is a pedagogical approach which involves the engagement of groups of learners in extended periods of online intercultural interaction and collaboration with partners from other cultural contexts or geographical locations as an integrated part of their educational programmes and under the guidance of educators and/or expert facilitators” (p. 478).
\end{abstract}

Three key components of this definition provide context for our approach to VE as a pedagogy for IaH: "collaboration with partners from other cultural contexts", "integrated part of their education 
programmes", and "under the guidance of educators and/or expert facilitators". These ideas align with the above-mentioned Chinese State Council's (2019) Modernisation of Education 2035 plan to improve international exchange and cooperation within mutual learning environments between China and other countries.

The positive impact of VE on foreign language and intercultural communication has been widely documented, especially in second language learning and teaching contexts (see Hauck \& MüllerHartmann, 2020; O’Dowd \& Dooly, 2020; O’Dowd \& Lewis, 2016). VE can have a "positive impact on perceived self-esteem, curiosity, intercultural sensitivity, reflection on beliefs and behaviours, ability to see complexity in intercultural communication" (Satar, 2021, p. 1), and awareness of the limits of understanding of cultural differences as binary relationships in categories of 'us' and 'them' (Helm \& van der Velden, 2019).

VE is an international and intercultural exercise (De Wit, 2016). It can afford "environmentally sustainable, accessible, equitable, and meaningful intercultural and multinational experiences" (Satar, 2021, p.1). Yet, "experiences of international collaboration based on principles of mutuality and reciprocity are somewhat lacking” (Helm \& Beaven, 2020, p. 30). We address this gap with the VE example we present in section 4.2 whereby we describe a reciprocal VE partnership built on mutual intercultural understanding of and respect for the socio-cultural, political, and educational realities of each partner.

In relation to VE implementation in the global East, and specifically in China, previous research has largely focused on the impact of VE on learners' linguistic and IC development. Within the context of tandem exchanges, several studies have reported perceived gains in language proficiency and intercultural understanding (see Kan, Stickler, \& Xu, 2013; Tian \& Wang, 2010; Wang-Szilas, Berger, \& Zhang, 2013). Pre-project preparation, continuous support for learners, and careful task design have been identified as key elements for successful VE collaboration with Chinese institutions (Chun, 2014; Kan et al., 2013).

More recent research has investigated concepts beyond linguistic and IC gains, which are also relevant to HE internationalisation efforts. Compensatory communication strategies have been observed to help Chinese learners of English to establish more immediate relationships (Feng \& Shirvani, 2021). Szobonya and Roche (2021) explored the potential of VE on the engagement of new generations with sustainable development goals in a study on VEs organised between a community college in the USA and Morocco, China, and Iraq. They argue that VE can create global connections in that "[VE] can unite this cohort of budding activists to come together in a welcoming, educative environment to make the world a better place for all citizens” (Szobonya \& Roche, 2021, p. 27). 
In a large-scale survey of HE students in Asia-Pacific countries, positive learner outcomes were identified, especially in relation to developing an open-minded stance free from stereotypes with a focus on multicultural understanding and conflict resolution (Watanabe, 2020). Other studies have explored barriers to systematic implementation of VE in the Asia-Pacific region (Hagley \& Wang, 2020). Yet although staff are key stakeholders in internationalisation, their perspectives on VE within the Chinese HE global agenda has not been explored.

\section{Methodology}

The project, Enhancing internationalisation of Chinese HEI: an intercultural approach, is a partnership between two institutions in the UK and China. The project explored how staff at one Chinese university understand and experience internationalisation and the role of VE within this context. The project consists of three phases as detailed in Table 1.

Table 1. Project overview

\begin{tabular}{|l|l|l|}
\hline Phase and focus & Project activities & Data collected \\
\hline $\begin{array}{l}\text { Phase } 1 \\
\text { IaH at the individual } \\
\text { and strategic level }\end{array}$ & $\begin{array}{l}\text { project set up; } \\
\text { on-site training on interculturality } \\
\text { to Chinese staff and students }\end{array}$ & $\begin{array}{l}\text { 3 focus group interviews with } \\
\text { 23 Chinese undergraduate students } \\
\text { on their perceptions of IaH }\end{array}$ \\
\hline $\begin{array}{l}\text { Phase 2 } \\
\text { The role of VE in relation to IaH }\end{array}$ & $\begin{array}{l}\text { online training and data collection } \\
\text { for staff about VE and IaH }\end{array}$ & $\begin{array}{l}\text { audio-recorded interactions with 15 staff } \\
\text { members (involved in Phase 1) during two } \\
\text { online training sessions on IaH and VE; } \\
\text { one follow-up semi-structured interview (90 } \\
\text { minutes) with two key informants (China and } \\
\text { US) who had organised a VE for their students }\end{array}$ \\
\hline $\begin{array}{l}\text { Phase 3 (in process) } \\
\text { Strategic directions }\end{array}$ & $\begin{array}{l}\text { not yet completed } \\
\text { with students about VE and IaH }\end{array}$ & \\
\hline
\end{tabular}

We collected data through two, 90-minute online training sessions and one follow-up semi-structured interview with two informants, based in China and the US respectively, who had organised a VE between their students. The training was designed for staff at the Chinese institution with an interest in internationalisation and VE theory and practice. To prepare participants for the training, we shared learning materials with them in advance, including a glossary of key terms (Appendix A).

The topics for the two training sessions were:

- Session 1: What is VE? How can it help IaH?

- Session 2: Different types of VE; How can VE work at [name of institution]? 
The training was designed based on principles of constructivism in which teacher-led presentations were kept to a minimum and participants were encouraged to reflect on their own experiences. Key mechanisms for ensuring active learning included open-ended questions and guided discussion on the following topics: (1) involvement with teaching and research activities at their institution; (2) understanding of IaH and practical examples; (3) understanding of VE theory; and (4) experiences of VE. Training took place via videoconferencing, and participants were invited to contribute to the group discussions via audio, text chat, and polls.

\subsection{Context and participants}

We chose our research site for three reasons: (1) It is a 100-year-old leading Tier 1 institution ranked second in China for scientific research and part of the G74; (2) It has a high proportion of students from ethnic minority and low-income families who are less likely to take part in study abroad; and (3) the authors had previous connections and were interested in developing further academic collaborations.

The training (Phase 2) included 15 participant-interviewees from various disciplines: ten were scholars in academic English, cultural studies, and linguistics; two in engineering; one in law; and two in foreign languages. All participants were first language speakers of Chinese with varying competence in English. They all had teaching duties, and some had previously worked with international students. However, only one participant, whom we invited for a follow-up interview, had experience with organising a VE. The identification of participants was purposive (Ellis \& Barkhuizen, 2005). They were recruited through our contacts and through a call for participants in a local staff WeChat ${ }^{5}$ group.

\subsection{Data collection}

The data include six hours of audio-recorded interactions (the VE training sessions) and one followup semi-structured interview (90 minutes). We conducted follow-up interviews with TM, a Chinese participant in our training, and NC, a community college teacher based in the USA who was their VE partner. We focused on: (1) contextual information about the participants' roles and collaborations; (2) context and details of the VE; and (3) opportunities, challenges, and ways forward. The interview questions are detailed in Appendix B.

4. G7 (工信部高校联盟; G7联盟) is a Chinese university union of seven universities directly under the administration of gongxin bu (工信部，Ministry of Industry and Information Technology of PRC). All of these are national key universities striving to become first rate world universities.

5. WeChat, the largest social media platform in China, is a multi-purpose social media, messaging and payment app similar to WhatsApp. 


\subsection{Data analysis}

Here, we present qualitative findings from the second phase of the project during which we conducted training for staff on VE and IaH. Social constructionism (Berger \& Luckmann, 1966; Gergen, 2009), which is primarily concerned with human experiences and how people understand them, offered us a theoretical lens for exploring how staff members construct the concept of IaH and the potential role of VE within IaH.

All data were transcribed verbatim, checked for accuracy, and analysed thematically following Strauss and Corbin's (1990) grounded theory analysis. As suggested by Charmaz (2006), we conducted a comprehensive literature review after developing an in-depth analysis of our data set, to avoid preconceived theories determining the outcome of the study.

In our analysis, we used theoretical memos (Corbin \& Strauss, 1990) to support the formulation and revision of theory. We followed three suggested steps: (1) open coding which involved breaking down the textual data into discrete parts and identifying initial codes to label them; (2) axial coding which enabled us to draw connections between the initial codes, and (3) selective coding which involved selecting overarching themes that connect the codes and contribute to a coherent narrative and discarding codes without sufficient supporting data. Following Strauss and Corbin (1990), we aimed for conceptual saturation and engaged in constant comparison. We actively sought any potential new codes and themes and explored relationships and contradictions across themes.

\subsection{Ethics, researcher positioning, and evaluation of the study}

The study received full ethical approval from both universities. Informed consent was gained from participants prior to data collection. All data were anonymised and managed in compliance with the EU General Data Protection Regulation.

To evaluate the quality of our study, we followed Lincoln and Guba's (1985) conceptualisation of trustworthiness in qualitative research. This refers to how truthful, replicable, and transferable the findings are and whether the study has been conducted consistently and neutrally (Lincoln \& Guba, 1985). We ensured trustworthiness by acknowledging and describing our position as researchers and the theoretical and methodological underpinnings of the study. Furthermore, we used participants' checking during the data collection to confirm or correct our understandings, thus reducing the effect of researcher bias. Rapport building with participants was also fundamental to developing trust and therefore led to findings with a higher ‘truth value’ (Lincoln \& Guba, 1985). 


\section{Analysis}

We provide an analysis of the data from the two training sessions followed by an analysis of the follow-up interview before considering them in relation to one another and to the relevant literature. Our analysis revealed the following themes (Table 2).

Table 2. Overview of themes

\begin{tabular}{|l|l|}
\hline Themes from the training & Themes from the Chinese-American VE \\
\hline IaH and the creation of an international campus & Forming VE partnerships with China \\
\hline Internationalisation and VE & Power dynamics \\
\hline VE and the creation of equal learning opportunities & Interplay of technical and political challenges \\
\hline Linguistic, pedagogical, and technological challenges of VE & \\
\hline
\end{tabular}

\subsection{Themes from the training discussions}

\subsubsection{IaH and the creation of an international campus}

Training participants were initially asked to discuss their understanding of IaH. This was particularly important as $\mathrm{IaH}$ has been theorised and operationalised in different educational contexts (e.g. Beelen \& Jones, 2015; Guimarães et al., 2019; Robson, 2017) and it is a relatively new concept in Chinese HE. A common theme throughout the data was how the creation of an international campus represents both an important and challenging endeavour. This excerpt provides an example.

KX: [Internationalisation is about] 1. Students can make international friends in campus; 2. international professors, teaching materials, conference

TM: engagement in international and intercultural processes without physically being abroad

KX: international culture and activities. Engagement in international and intercultural processes without physically being abroad. Agree with that. (Excerpt 1, Training 1, written comments in chat)

It was agreed that the presence of international staff and students on campus alone does not imply that intercultural learning occurs. Instead, participants shared how encounters between Chinese and international students can actually be problematic. In the excerpt below, KX, who had explained 
that the university organises on campus activities for local and international students, shared her concerns about the benefit of such activities.

KX: When our students meet the international students. They really, actually, they don't have too many things to say after saying hello, my name is like this. Nice to meet you. I don't think that it depends on the level of language, but it depends on the culture, they have nothing in common, nothing to share.

Ganassin: No, it's not just about having international students on campus. It's about the understanding.

KA: Yes. It’s about intercultural understanding. (Excerpt 2, Training 1)

Participants' accounts demonstrate that interculturality needs an active effort from all of the stakeholders involved. Critical intercultural awareness is seen as key to internationalisation, which is "a new concept to most Chinese" (training participant) and support (e.g. in the form of training) is needed for those involved to be able to engage in intercultural encounters.

TM: internationalisation is everyone's business. It's not just the business of the International Office.... And an intercultural perspective is particularly important because if we don't have the critical intercultural awareness, if we do not know how to manage relationships and how to understand the meanings and negotiate to the meanings ... without an intercultural perspective well, internationalisation cannot be realised [...] IaH, actually, this is quite a new concept to most Chinese ... I think, adequate training in terms of intercultural communication or like cultural differences in the culture of learning. (Excerpt 3, Training 1)

\subsubsection{Internationalisation and VE}

Overall, participants' accounts showed that the training helped them to realise that intercultural encounters do not always require physical interaction, but VE can effectively support intercultural learning and contribute to the IaH of Chinese universities.

TM: VE has great potential for students and teachers to encounter the cultural other and engage in real life intercultural interactions; a convenient yet effective way to 'socialise' in an intercultural environment and to cultivate intercultural personhood and global citizenship. For the teachers, VE offers more opportunities for intercultural and international collaboration, which will benefit the students through teaching. (Excerpt 4, Training 2) 
Participants agreed that a VE experience must allow exchanges between people from different cultures and that such exchanges need to be facilitated.

$\mathrm{NH}$ : The most important word for VE must be people to people communication and then guided communication [...] there must be some people to guide this kind of communication and the people should have diverse backgrounds of culture or nationalities, or something else. And ... they should communicate and cooperate. (Excerpt 5, Training 1)

\subsubsection{VE and the creation of equal learning opportunities}

A further common theme highlights the ways in which VE promises to be an ideal context for providing equality in international experiences. The Covid-19 emergency, in May 2020 when the data were collected, had forced all participants to teach online for an entire semester. Some of their learners, who had access only through mobile phones, were still able to access content and interact with others. These experiences were an indication for staff that online interaction can in fact act as a means for creating equal learning opportunities.

ZC: ... students have different family background have different situations. And some of us use mobile phone the whole semester, the whole semester [is] now online teaching. And so, if we see these as equal opportunities with staff and students, yes they are. (Excerpt 6, Training 1)

TM, who had previous experience of VE, added that VE is a less elitist experience compared to more traditional physical mobility. This was particularly important in our research context, as the university had a sizeable proportion of students from low-income families who often lack the financial means to study abroad.

TM [VE offers] ... equal opportunities for all. Because it doesn't work in a very selective manner as with some exchange programmes, physical exchange programmes. (Excerpt 7, Training 1)

Overall, participants agreed that VE could contribute to strategies to enhance the quality of education being provided by staff to students across different disciplines.

IS: I think I just noticed one thing is quality of education. I think that VE skills can help us to provide and develop our [own] quality of education. (Excerpt 8, Training 1) 
TM: I think central to all these is quality education if we have quality education, we can train the students to solve all those problems for sustainable development. ... I think all over the world and across China there is an emphasis on the development or.. cultivation of global talents... All these things, I think, VE because of its international and intercultural approach is very unique. For students of all disciplines [and] disciplinary areas, of education at all levels. To work towards that big goal [of] quality education. (Excerpt 9, Training 1)

\subsubsection{Linguistic, pedagogical, and technological challenges of VE}

Participants discussed a number of challenges (i.e. fluency in English, time differences, different curricular requirements) related to planning and implementation of VE. These require decision making from the teachers and have a potential impact on the success of a VE. Interestingly, one participant expressed a belief that VE interactions would need to adopt English as a lingua franca, and this was seen to pose a potential problem of catering to learners with different language skills.

XU: We need to speak English, rather than other language to share information as the world language, so language fluency will be quality for us, the basic quality. And also, if the professors need to prepare for this kind of training or classes, that is a challenge for them because they have to design the course or the training suitable for the [unclear] from different backgrounds and different language level learners. (Excerpt 10, Training 2)

Lack of flexibility in terms of adapting the curriculum represents a further constraint for teachers (e.g. see Hagley \& Wang, 2020). As TM explained, once teaching plans have been submitted, there is little flexibility:

TM: We don't have much power in making arrangements of our teaching plans. Once we submit our teaching plans [...] If I want to make any change [...] I need to apply in the university system that there is a change of class hours. (Excerpt 11, Training 2)

Participants acknowledged that partner institutions working with China can find technologies that can be compatible and available across countries but integrating these technologies in a streamlined platform (e.g. one-stop-shop) was perceived as a further technological challenge.

NH: There are some more challenges. [...] First, first of all, that's about the platform ... or the technology equivalence, or the communication platform that students from different 
countries can use. [To] communicate in the cyber space that we need to have different channels such as the Zoom, the WeChat, or other social network apps or the communication tools that we need to use, but we need a formal way to keep everything on the right track. VE needs to use technology that keeps up with trends and to combine them together to make it sustainable. (Excerpt 12, Training 2)

These challenges are explored further in the VE example below.

\subsection{The Chinese-American VE Example}

In this section, we present the only VE case that was brought to our attention during the training, which was organised by TM. We invited both TM and her VE partner from the US (referred to here as NC) to a joint interview to enable a deeper understanding of the role of VE as part of IaH at the Chinese institution, how the exchange was set up, any benefits they perceived, and challenges they faced, as well as their future plans. Table 3 provides an overview of this Chinese-American VE partnership. Appendix C includes more background information about this VE example.

Table 3. The Chinese-American VE partnership

\begin{tabular}{|l|l|l|}
\hline & VE partner in China & VE partner in the USA \\
\hline Education level & HE (graduate) & Community college \\
\hline Subject & $\begin{array}{l}\text { Business writing for speakers of } \\
\text { English as foreign language }\end{array}$ & Business writing \\
\hline First language & Chinese & English \\
\hline Language of the exchange & English & English \\
\hline Number of participants & 15 & 7 \\
\hline Student roles & Author (writing) & Editor (feedback provision) \\
\hline Integrated into the course syllabus & Yes & Yes \\
\hline Formal assessment & Yes & No \\
\hline Objectives & $\begin{array}{l}\text { English language, communication, } \\
\text { and writing skills }\end{array}$ & Intercultural learning \\
\hline Duration & 1 month & \\
\hline Number of iterations & 1 (2019-2020 academic year) & \\
\hline Communication & $\begin{array}{l}\text { students: asynchronous (email) } \\
\text { teachers: asynchronous (QQ, a Chinese instant messaging software, and WeChat) }\end{array}$ \\
\hline
\end{tabular}

Three essential themes emerged from the interview data and are discussed below. 


\subsubsection{Forming VE partnerships with China}

A physical mobility activity of NC in China led to the development of informal acquaintance with TM. Rapport and intercultural affinity were especially important for TM who believed that "to understand China and the Chinese" was a prerequisite to working together.

TM: Also, we feel very fortunate to be able to work with (NC)... I think you need to know China to know the Chinese and there's not so many understand the China and the Chinese so well. So (NC)'s really came quite a pleasant experience and she could understand us, and even the difficulties we had and she had been very, very supportive.

\subsubsection{Power dynamics}

Seven US-based students participated in the exchange. They came from disadvantaged backgrounds and had low academic aspirations. During the Covid-19 pandemic they had little access to IT outside the classroom, while students in China had access to content at least on a smartphone (as reported by YB in Excerpt 6). At the Chinese university, 15 students took part. They were engineering students, high-achievers, and motivated for academic success and writing. The language of the exchange was English, thus positioning the American students in a status of symbolic power, yet their writing skills and motivations were not high. For the Chinese students, while they were second language speakers of English, they were highly responsible, keen to learn, and expected to receive feedback on their language use. These relationship dynamics between the student cohorts were unexpected. The Chinese institution and students were deemed to be in a higher position of academic power, at least as perceived by NC.

NC:... well for my students that [the different system and different pressures of Chinese students] would be interesting for them to understand, I mean, they don't... rub shoulders with young engineers or, you know,... some of my students wouldn’t normally interact with that kind of student anyway in any country.

The perceived power dynamics between the student cohorts led to certain task design decisions. NC and TM designed a writing task i.e. the creation of a promotional letter, that could be incorporated into the business writing course syllabi at both institutions. To put the students on 'equal footing', Chinese students took on the author role and the American students were assigned the editor role. The editorial role would normally indicate more power to students who are already first language speakers of English. However, given the American students' educational background, particularly 
their limited writing skills, and aspirations, the instructors perceived this set up to be more equal with Chinese students responsible for producing content.

NC: The exchange doesn't have to be symmetrical... So, we were trying to ... put our students on equal footing and, you know, it seemed like ... that was going to be difficult to do, now, because of the difference in English levels. And so, so I propose that... my students could be editors and [...] it would be good for her students to be producing the content.

\subsubsection{Interplay of technical and political challenges}

Particular challenges faced in this partnership were due to the interplay of technical and political realities. First, it was difficult to find communication platforms that would be accessible and work without problems in both countries. While the Chinese partner did not have reliable access to Zoom ${ }^{\circledR}$ through their institution, NC did not feel comfortable requiring US learners to install Chinese software, such as WeChat, given volatile political relationships between the two countries. Second, both TM and NC had experienced unreliable access to international software in China. Thus, they decided that email was the most reliable method for interaction. While email was perceived to be a communication medium posing the least risk of failure, at times it was still problematic, as emails from China were often automatically routed to the spam folders of the US students. One final challenge was bureaucratic red tape. For instance, TM reported that institutional procedures were required to make changes in the curriculum or approval was necessary to organise international events. These points are illustrated in the following excerpts.

NC: The problem is finding systems that will work in both countries. ... I would have preferred to have use WeChat..., but ... [...] frankly, in the current political climate here [...] we couldn't do anything that would have required the students (in China) to have a VPN. So, you know, there were a lot of technical political you know, which is what sort of had us use email.

NC: One thing I want you to understand is that we always run the risk of having one side or the other shut down. Whatever it is, we're trying to do. ... Well, you know, the United States pulled the licenses for MATLAB for all of China. ... Everything's very fraught.

TM: Yeah... we need to apply plans when they want. We have an organised event with internationals, we are, even without internationals if it's not within the curriculum, and an event, we need to apply, okay, go through the process. 
Despite these challenges, NC and TM reported that their VE initiative has been a positive experience deemed 'absolutely critical' for the students.

\section{Findings and discussion}

Our analysis yielded insight into the conceptual interface between internationalisation and interculturality - our construal of interculturality underpins the various interpretations of internationalisation. Concerning our first research question, i.e. how teachers and administrators understand $\mathrm{IaH}$, our participants agreed on the importance of enabling meaningful interactions on campus for all involved (e.g. local and international students). Their accounts showed that intercultural learning on campus requires ongoing effort and active participation from all stakeholders so that students and staff can be supported to recognise complexity in self and others. In participants' views, training is essential not just for students but for staff across the university to create activities that support intercultural learning and therefore IaH.

Regarding our second research question; i.e. which role VE plays in the process of IaH, our analysis showed that staff members believed VE can contribute to IaH because it has the potential to support intercultural learning between learners of different lingua-cultural backgrounds without physical interaction (Dooly, 2017; O'Dowd \& Lewis, 2016). Staff recognised that sharing the same physical location does not necessarily mean that local and international students will engage in successful intercultural exchanges. However, according to participants, VE can create a more natural opportunity for interactions between students to be facilitated, thus overcoming these issues, and creating conditions for intercultural exchange. Participants also perceived VE to provide learning opportunities for staff to develop their own intercultural skills which in turn benefits their students and increases the quality of education across disciplines.

The example VE explored here indicated that key drivers for VE were positive attitudes and openness towards other cultures, intercultural understanding, mutual pedagogical interest in international collaboration, as well as rapport and intercultural affinity between the VE partner instructors. In this case, the instructors met organically, slowly establishing trust and rapport during the American instructor's visits to China. This kind of collaboration based on mutuality and reciprocity is rare (Helm \& Beaven, 2020) and not all instructors can be expected to develop similar opportunities on their own.

Finally, our third research question examined the opportunities and challenges in VE implementation for IaH. Our analysis revealed several challenges that participants either anticipated or experienced 
in relation to planning and implementation of VE (i.e. language skills, time differences between countries, requirements of the different curricula, use of technology, and issues related to the political climate). These findings are consistent with what is reported in the current body of VE literature (e.g. Hagley \& Wang, 2020; Kan et al., 2013). In relation to technological challenges, lack of streamlined and reliable VE tools or software compatible with the infrastructure of partner countries, largely due to volatile political relationships, was identified as a major challenge. Other organisational challenges involved excessive bureaucracy to request curricular changes for VE implementation and for international events. These two points were more specific and novel to the context of this VE. This VE example took place during the Trump administration in the US, which meant increased potential tensions between the US and China that impacted on participants' ability to access shared VE platforms and software. Internal institutional challenges experienced at the Chinese institution was an element not reported in previous studies.

Finally, we demonstrated that power dynamics between VE participants might be unexpected and can be managed with an accommodating VE design. In our VE example, the socio-cultural background and the educational aspirations of the cohorts were such that they ran counter to expectations. Previous VE literature with Chinese institutions tends to depict a deficit view towards English language proficiency levels of Chinese learners of English (Feng \& Shirvani, 2021; Tian \& Wang, 2010). Yet, we observed interesting power dynamics in the Chinese-American VE example. The American instructor spoke highly of the academic aspirations and sense of responsibility of the Chinese students, reflecting on the low level of English writing skills of her own students. She suggested that the American students assume the 'editorial' role in the writing task to ensure 'equal footing'. Our results indicate that VE researchers and organisers need to break free from a deficit language view of Chinese students and strive to establish partnerships and task design that can empower learners at both institutions.

\section{Implications and recommendations}

Grounded in our findings, we offer several implications and recommendations.

First, our study suggests that facilitated partner-finding mechanisms may be an essential prerequisite for successful VE. Such mechanisms could involve staff-staff VEs to be organised (e.g. by internationalisation officers) at partner institutions. During these staff-staff VEs, instructors can initially develop mutual intercultural understandings and interpersonal relationships amongst themselves before planning for the integration and implementation of VE as part of their corresponding curricula. 
Second, developing international partnerships for VE requires engagement and commitment at the institutional level. Similarly, institutional leaders, including international offices, should be instrumental in enhancing interculturality amongst staff. We suggest that the identification of strategic partners should not only happen at teacher-teacher level, but at a university-university level where there is commitment and support for the work of developing lasting VE partnerships. Commitment to VE at the institutional level is beginning to emerge, as the field of VE matures and becomes recognised as viable, but these efforts remain under-documented in VE research.

Finally, we encourage decision makers to consider VE in languages other than English, including Chinese, in the view that any language could serve as a lingua franca. VE instructors have a responsibility to consider how the choice of certain languages might contribute to uneven power dynamics amongst learners and between learners and teachers. Such a process of negotiation is particularly significant in the context of Chinese HE where internationalisation and IaH are largely understood in terms of adoption of English as a language of teaching (Song, 2018), in the view that the criteria for determining world-class universities and the sharing of best practice are based on 'Western' norms where English is central (Wei \& Johnstone, 2020). VE projects where languages other than English are adopted could play a key role in challenging the hegemony of English in VE practice (see Helm \& Acconcia, 2019).

The study presented here was qualitative in nature and small in scale as we aimed at providing insights from participants at a specific institution. Following Robson et al. (2018), we were interested in exploring the perspectives of staff members, in the view that these are central to successful IaH strategies. Further studies on IaH in Chinese HE could firstly investigate the contextualised trajectories of students and experiences of IaH and, secondly, explore their aspirations and issues in terms of IaH, interculturality, and VE. Attention should also be paid in further research to the intersectionality of gender, minority, and socio-economic status to assess how different groups can be supported to equitably access opportunities of IaH.

We have discussed the ways in which VE can support IaH opportunities particularly for the non-mobile students in China and explored challenges in establishing VEs with Chinese partner institutions. Yet it is important to emphasise that VE implementation should not be considered as a replacement for physical mobility. HEIs (both in China and around the world) should combine physical, blended, and VE options in their IaH strategies to foster "greater opportunities to integrate an international learning experience into their portfolio" (Buiskool \& Hudepohl, 2020, p. 6). The interplay of technical and political challenges must be considered by all stakeholders involved in the implementation of VEs with Chinese institutions. Our findings invite new thinking on the importance for all stakeholders to develop awareness of certain intricacies of working with China. It is of key 
importance that institutions and individuals are prepared to increase personal and institutional links for better political relationships in the long term through enhanced mutual intercultural understanding. Although China has the reputation of being a challenging partner country, we believe that it is not more or less challenging than other contexts. Instead, research-informed understanding of the issues that researchers and VE instructors can encounter is lacking. Via this study, we hope to have contributed to this understanding.

\section{Acknowledgements}

We are grateful to WenWen Zhang, Yao Wang, and Prof Song Li for the support on the project.

\section{Disclosure statement}

No potential conflict of interest was reported by the authors.

\section{Funding}

This paper is informed by a pilot study funded by the Newcastle University Humanities \& Social Sciences Faculty Fund (2019-2021).

\section{Appendices}

- Appendix A: Glossary of key terms Internationalisation and VE

- Appendix B: Full list of interview questions (VE example)

- Appendix C: background information (VE example)

\section{References}

ATIAH. (2018). Self-audit tool: self-evaluating internationalisation at home. https://research.ncl.ac.uk/atiah/outputs/Selfaudit_ATIAH\%20EN.pdf

Barrett, M., Byram, M., Lazar, I., Mompoint-Gaillard, P., \& Philippou, S., (2013). Developing intercultural competence through education. Council of Europe. 
Beelen, J., \& Jones, E. (2015). Redefining internationalization at home. In A. Curaj, L. Matei, R. Pricopie, J. Salmi \& P. Scott (Eds), The European higher education area: between critical reflections and future policies (pp. 59-72). Springer. Berger, P. S., \& Luckmann, T. (1966). The social construction of reality: a treatise in the sociology of knowledge. Doubleday. Buiskool, B., \& Hudepohl, M. (2020). Research for CULT committee - virtual formats versus physical mobility. Concomitant expertise for INI report. https://www.europarl.europa.eu/RegData/etudes/BRIE/2020/629217/IP

Charmaz, K. (2006). Constructing grounded theory: a practical guide through qualitative analysis. Sage.

Chun, D. M. (2014). (Ed.). Cultura-inspired intercultural exchanges: focus on Asian and Pacific languages. National Foreign Language Resource Center, University of Hawai‘i at Mānoa.

Corbin, J., \& Strauss, A. (1990). Grounded theory research: procedures, canons and evaluative criteria. Qualitative Sociology, 13, 3-21. https://doi.org/10.1007/BF00988593

De Wit, H. (2016). Internationalisation and the role of online intercultural exchange. In R. O'Dowd \& T. Lewis (Eds), Online intercultural exchange: policy, pedagogy, practice (pp. 192-208). Routledge.

Dooly, M. (2017). Telecollaboration. In C. Chapelle \& S. Sauro (Eds), The handbook of technology and second language teaching (pp. 169-182). Wiley.

Ellis, R., \& Barkhuizen, G. (2005). Analysing learner language. Oxford University.

Feng, R., \& Shirvani, S. (2021). Compensatory strategies adopted by Chinese EFL learners in virtual exchange with native speakers. In M. Satar (Ed.), Virtual exchange: towards digital equity in internationalisation (pp. 63-71). Research-publishing.net. https://doi.org/10.14705/rpnet.2021.53.1290

Gergen, K. (2009). An invitation to social construction. Sage.

Guimarães, F. F., Mendes, A. R. M., Rodrigues, L. M., Paiva, R. S. dos S., \& Finardi, K. R. (2019). Internationalization at home, COIL and intercomprehension: for more inclusive activities in the global south. Simon Fraser University Educational Review Journal, 12(3), 90-109.

Hagley, E., \& Wang, Y. (2020). (Eds). Virtual exchange in the Asia-Pacific: research and practice. Research-publishing.net. https://doi.org/10.14705/rpnet.2020.47.9782490057788

Hauck, M., \& Müller-Hartmann, A. (2020). (Eds). Virtual exchange and 21st century teacher education: short papers from the 2019 EVALUATE conference. Research-publishing.net. https://doi.org/10.14705/rpnet.2020.46.9782490057801

Helm, F., \& Acconcia, G. (2019). Interculturality and language in Erasmus+ Virtual Exchange. European Journal of Language Policy, 11(2), 211-233. https://www.muse.jhu.edu/article/737426

Helm, F., \& Beaven, A. (2020). (Eds). Designing and implementing virtual exchange - a collection of case studies. Researchpublishing.net. https://doi.org/10.14705/rpnet.2020.45.9782490057726

Helm, F., \& van der Velden, B. (2019). Erasmus+ Virtual Exchange intercultural learning experiences: 2018 impact report. European Union and EACEA. https://europa.eu/youth/sites/default/files/eyp/eve/attachments/181025_eve_-preliminary_impact_review_jan-june_2018_1.pdf

Holmes, P., \& O’Neill, G. (2012). Developing and evaluating intercultural competence: ethnographies of intercultural encounters. International Journal of Intercultural Relations, 36(5), 707-718.

Kan, Q., Stickler, U., \& Xu, C. (2013). Chinese-English eTandem learning: the role of pre-project preparation and collaboration. Chinese Language Globalisation Studies, 2(5), 1-10. 
Knight, J. (2004). Internationalization remodelled: definition, approaches, and rationales. Journal of Studies in International Education, 8(5), 5-31.

Kramsch, C. (1998). Language and culture. Oxford University.

Krebs, K., C. (2020). Global, international and intercultural learning in university classrooms across the disciplines. Research in Comparative \& International Education, 15(1), 36-51.

Lincoln, Y. S., \& Guba, E. G. (1985). Naturalistic inquiry. Sage.

Liu, Q., Turner, D., \& Jing, X. (2019). The “double first-class initiative” in China: background, implementation, and potential problems. Beijing International Review of Education, 1(1),92-108. https://doi.org/10.1163/2590254700101009

Liu, N. C., Wang, Q., \& Cheng, Y. (2011). Paths to a world-class university: lessons from practices and experiences. SensePublishers

MOE. (2018). Ministry of Education, People's Republic of China.统筹推进世界一流大学和一流学科建设实施办法 (暂行). [Tentative Methods for Coordinating Development of World-Class Universities and World-Class Disciplines]. http:// www.moe.gov.cn/srcsite/A22/moe_843/201701/t20170125_295701.html

National Foreign Language Teaching Advisory Board 高等学校外语专业教学指导委员会(2018), 《普通高等学校本科专业 类教学质量国家标准 (外国语言文学类) 》(National Standards for the Quality of Foreign Language and Literature Education), 高等教育出版社.

O'Dowd, R. (2020). A transnational model of virtual exchange for global citizenship education. Language Teaching, 53(4), 477-490. https://doi.org/10.1017/s0261444819000077

O’Dowd, R. (2021). Virtual exchange: moving forward into the next decade. Computer Assisted Language Learning, 34(3), 209-224.

O’Dowd, R., \& Dooly, M. (2020). Intercultural communicative competence development through telecollaboration and virtual exchange. In J. Jackson (Ed.), The Routledge handbook of language and intercultural communication (pp. 361375). Routledge.

O’Dowd, R., \& Lewis, T. (2016). (Eds). Online intercultural exchange: policy, pedagogy, practice. Routledge.

Robson, S. (2017). Internationalization at home: internationalizing the university experience of staff and students. Revista Educação, 40(3), 368-374.

Robson, S., Almeida, J., \& Schartner, A. (2018). Internationalization at home: time for review and development? European Journal of Higher Education, 8(1), 19-35.

Satar, M. (2021). Introducing virtual exchange: towards digital equity in internationalisation. In M. Satar (Ed.), Virtual exchange: towards digital equity in internationalisation (pp. 1-13). Research-publishing.net. https://doi.org/10.14705/ rpnet.2021.53.1285

Song, J. (2018). Creating world-class universities in China: strategies and impacts at a renowned research university. Higher Education, 75, 729-742.

Spitzberg, B. H., \& Changnon, G. (2009). Conceptualizing intercultural competence. In D. K. Deardorff (Ed.), The Sage handbook of intercultural competence (pp. 2-52). Sage. 
State Council. (2015). 国务院关于印发统筹推进世界一流大学和一流学科建设总体方案 [Overall plan on coordinating development of world-class universities and world-class disciplines]. People’s Republic of China. http://www.gov.cn/ zhengce/content/2015-11/05/content_10269.htm

State Council. (2019). Modernization of Chinese Education 2035. 国务院. 中国教育现代化2035. People’s Republic of China. http://www.gov.cn/zhengce/2019-02/23/content_5367987.htm

Strauss, A., \& Corbin, J. (1990). Basics of qualitative research: grounded theory procedures and techniques. Sage Publications.

Sun, Y. Z., Liao, H. J., Zheng, X., \& Qin, S. Q. (2021). 《跨文化外语教学研究》 (Research on Intercultural Foreign Language Teaching and Learning). 外语教学与研究出版社. Foreign Language Teaching and Research Press.

Szobonya, P., \& Roche, C. (2021). Intercultural youth: the global generation and virtual exchange. In M. Satar (Ed.), Virtual exchange: towards digital equity in internationalisation (pp. 17-28). Research-publishing.net. https://doi. org/10.14705/rpnet.2021.53.1286

Tian, J., \& Wang, Y. (2010). Taking language learning outside the classroom: learners' perspectives of eTandem learning via Skype. Innovation in Language Learning and Teaching, 4(3), 181-197.

Wang, C. (2018). An exploration of students' experiences and interpretations of an internationalisation policy implemented in a Chinese university: a case study. Durham Theses, Durham University. http://etheses.dur.ac.uk/12626/

Wang-Szilas, J., Berger, C., \& Zhang, F. (2013). eTandem language learning integrated in the curriculum: reflection from students' perspectives. In M. F. Paulsen \& A. Szűcs (Eds), The joy of learning enhancing learning experience improving learning quality proceedings of the European Distance and E-Learning Network 2013 Annual Conference, University of Oslo, June 2013 (pp. 93-107).

Watanabe, M. (2020). Tackling international controversies in virtual exchange. In E. Hagley \& Y. Wang (Eds), Virtual exchange in the Asia-Pacific: research and practice (pp. 61-76). Research-publishing.net. https://doi.org/10.14705/ rpnet.2020.47.1146

Wei, Y., \& Johnstone, C. (2020). Examining the race for world-class universities in China: a culture script analysis. Higher Education, 79, 553-567.

Wihlborg, M., \& Robson, S. (2017). Internationalisation of higher education: drivers, rationales, priorities, values and impacts. European Journal of Higher Education, 8(1), 8-18.

Yang, R. (2014). China's strategy for the internationalization of higher education: an overview. Frontiers of Education in China, 9, 151-162. https://doi.org/10.1007/BF03397011

Young, T. J., Handford, M., \& Schartner, A. (2017). The internationalising university - an intercultural endeavour? Journal of Multilingual and Multicultural Development, 38(3), 189-191.

Zha, Q., Wu., H., \& Hayhoe, R. (2019). Why Chinese universities embrace internationalization: an exploration with two case studies. Higher Education, 78, 669-686.

Zhao, L. (2018). China's world-class 2.0: towards more institutionalized and participatory policymaking? Copenhagen Journal of Asian Studies, 36(1), 5-27. 


\section{Virtual Exchange?}

Published by University of Groningen Press | UGP, a not-for-profit press

Groningen, The Netherlands | UGP@rug.nl

(C) 2021 UNICollaboration (collective work)

(c) 2021 by Authors (individual work)

Journal of Virtual Exchange 2021

Special issue edited by Carine Ullom and Müge Satar

Publication date: 2021/12/17

Journal of Virtual Exchange (JVE) is an online, open-access, peer-reviewed journal aimed at practitioners and researchers in the field known variously as virtual exchange, telecollaboration, or online intercultural exchange. It is the official journal of UNICollaboration (https://www.UNICollaboration.org/), the international academic organisation dedicated to supporting and promoting telecollaboration and virtual exchange in higher-level education.

Rights. The whole volume is published under the Attribution-NonCommercial-NoDerivatives 4.0 International licence (CC BY-NCND 4.0); individual articles may have a different licence. Under the CC BY-NC-ND licence, the volume is freely available online for anybody to read, download, copy, and redistribute provided that the author(s), editorial team, and publisher are properly cited. Commercial use and derivative works are, however, not permitted.

Disclaimer. University of Groningen Press does not take any responsibility for the content of the pages written by the authors of this article. The authors have recognised that the work described was not published before, or that it was not under consideration for publication elsewhere. While the information in this article is believed to be true and accurate on the date of its going to press, neither UniCollaboration nor University of Groningen Press can accept any legal responsibility for any errors or omissions. Additionally, the publisher makes no warranty, expressed or implied, with respect to the material contained herein. While University of Groningen Press is committed to publishing works of integrity, the words are the authors' alone.

Trademark notice. Product or corporate names may be trademarks or registered trademarks, and are used only for identification and explanation without intent to infringe.

Copyrighted material. Every effort has been made by the editorial team to trace copyright holders and to obtain their permission for the use of copyrighted material in this article. In the event of errors or omissions, please notify the publisher of any corrections that will need to by incorporated in future editions of this article.

Typeset by Research-publishing.net (https://research-publishing.net)

Noto fonts are open source. All Noto fonts are published under the SIL Open Font License, Version 1.1. Noto is a trademark of Google Inc. (https://www.google.com/get/noto/).

ISSN: 2647-4832 (online only)

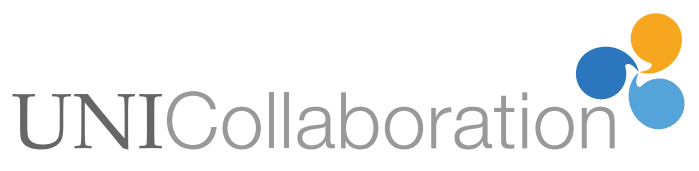




\section{Appendix A}

\section{Glossary of key terms re: Internationalisation and VE}

The glossary is part of the resources that the Chinese trainees had received, and it includes an overview of key terms made relevant to the context of Chinese HE (高校)

\section{Blended Learning}

an approach to education that combines online materials and interaction with place-based classroom methods. It requires the physical presence of both teacher and student, with some elements of student control over time, place, path, or pace of learning. (https://en.wikipedia.org/wiki/Blended_learning)

\section{Distance Education/Distance Learning}

an umbrella term for any learning that takes place across distance and not in a physical classroom. Traditionally, students corresponded with the school via post, listened to lessons on the radio or cassette players, or watched lessons on TV. Today, it involves online teaching and learning.

\section{Interculturality/intercultural}

how we engage with the 'other' in intercultural encounters and we reflect on ourselves. Intercultural encounters are spaces where people from different cultural, national, and social backgrounds talk to each other and to develop self-awareness. Intercultural encounters can also happen between people from the same country. For example, two Chinese people - a Cantonese speaker from Hong Kong and somebody from the 东北-can have an intercultural encounter.

\section{Internationalisation}

is about making universities more internationally-oriented. It can be implemented through a range of actions (e.g., presence of international staff and students, mobility programmes, international projects, modifications to curriculum to ensure global perspectives).

\section{Internationalisation at home (IaH)}

mainly concerned with the vast majority of nonmobile domestic students and staff . Internationalisation at home aims to promote, through a range of academic and social policies and support, the knowledge, attitudes, and skills that are essential for students to become global citizens, and to create an intercultural environment where positive crosscultural contacts may occur.

\section{Globalisation}

includes all processes by which organisations (e.g., businesses) operate on an international scale or develop international influence. Globalisation impacts on internationalisation (both in a positive and negative sense) but these are two very different phenomena.

\section{International project}

a (research) project developed between institutions based in different countries, for example, between a British and Chinese University.

\section{Project team}


all the people who work together in a project. For European research projects, a project team normally includes a PI (principal investigator) who manages the project, a number of coinvestigators that lead on different aspects, and Research Associates and Assistants who deliver different aspects of the project.

\section{Student/staff mobility}

an opportunity for students to spend some time studying abroad whilst undertaking their degree programme (for example, an Italian undergraduate student studying in China for a semester). Staff mobility refers to academic staff spending time to teach or research at another institution.

\section{Non mobile (staff/students)}

students and staff who, for various reasons (e.g., financial reasons, caring duties), do not take part in a mobility programme to go abroad to study/work.

\section{International classroom}

Generally, an international classroom includes international students, has an internationalised curriculum and is taught in English.

\section{For-profit providers (in Higher Education)}

agencies that recruit students in exchange for a fee.

\section{BRIC(S) countries}

the term includes Brazil, Russia, India, China (and South Africa).

\section{Virtual Exchange (VE)}

an educational practice that "involves the engagement of groups of learners in extended periods of online intercultural interaction and collaboration with international peers as an integrated part of their educational programs and under the guidance of educators and/or facilitators." (O'Dowd, 2018). Virtual Exchange is also known as Telecollaboration, Online Intercultural Exchange, Collaborative Online International Learning (COIL), International Online Learning, Globally Networked Learning, among others.

\section{Virtual mobility}

students and teachers in higher education using another institution outside their own country to study or teach online/via distance learning for a limited time, without physically leaving their home. It complements physical mobility in which students travel to study abroad, such as within the Erasmus Programme.

(https://en.wikipedia.org/wiki/Virtual_mobility)

\section{Digital Skills}

skills needed to find, evaluate, use, share, and create content using information technologies and the Internet.

\section{Equitable}

something that is fair in a way that it gives equal treatment to all those involved.

\section{Online Teaching and Learning}


education that takes place over the Internet. It is often referred to as e-learning and is just one type of distance education. Online learning courses can be offered synchronously or asynchronously.

\section{Sustainable}

something designed to continue over time without making harm (e.g., to the environment) and without having problems (in reference to VE).

Reference: O'Dowd, R. (2018). From telecollaboration to virtual exchange: state-of-the-art and the role of UNICollaboration in moving forward. Journal of Virtual Exchange, 1, 1-23. Research-publishing.net.

https://doi.org/10.14705/rpnet.2018.jve.1

\section{关键术语表}

主题：国际化和虚拟交换（VE）项目

背景：高校

混合式学习: 混合式学习是利用在线学习资料、进行线上互动, 并与实地课堂学习相结合的教 育方法。它需要教师和学生的共同参与, 但学生可以控制部分要素：时间、地点、路径或学习 速度。

远程教育：远程教育/远程学习是指不在实体教室中进行教学, 脱离距离限制的学习方式的总 称。过去, 学生们可以通过邮件与学校通信, 通过收音机或磁带收听课程, 或在电视上观看课 程。现在, 远程教育还包括在线教学和学习。

跨文化：跨文化是指我们如何在跨文化中与 “他者（other）”互动，以及我们如何反思自己。 跨文化接触则指来自不同文化、国家和社会背景的人们相互交流并发展自我意识。来自同一国 家的人们之间也可以发生跨文化接触。例如, 两个中国人（一个讲粤语的香港人和一个东北人 ）之间也可发生跨文化接触。

国际化：广义上, 国际化是指让校园更加面向国际。国际化可以通过一系列行动来实现。例如 ，招收国际教职工和学生，开展交换项目或国际项目。

在地国际化：在地国际化涉及的主要是本国校园内绝大多数非流动的本国学生和教职员工。国 内国际化旨在通过一系列学术政策、社会政策及相关支持, 培养学生成为全球公民所必需的知 识、态度和技能, 并创造跨文化环境以促进积极的跨文化接触。

全球化：指组织机构（例如企业）在国际范围内运作并发展国际影响力的所有过程。全球化可 对国际化产生正面或负面影响，但这两种现象完全不同！

国际项目：不同国家的机构共同开发的（研究）项目。如，英国与中国大学间的合作项目。 项目团队：项目团队包括项目中所有工作人员。以欧洲研究项目为例, 项目团队通常包括管理 项目的 PI（首席研究员）、几名分工不同的 CoI（共同调查员）以及负责项目不同方面的副研 究员和研究助理。 
学生/教师流动: 学生流动是指学生在攻读学位期间有机会在国外学习。例如, 在中国学习一 个学期的意大利本科生。教师流动是指教职人员在其他国家的机构任教或研究。

非流动（学生/教师）：是指由于各种原因（如经济原因、家庭原因）不能参加流动计划并出 国学习/工作的学生/教职员工。

国际课堂: 虽然相关定义很多, 但总的来说国际课堂具有三要素：拥有国际学生、提供国际化 课程, 并以英语授课。

盈利性中介（高校内）：以盈利为目的招收学生参加出国交换项目的中介机构。

BRIC(S)金砖国家：分别指巴西、俄罗斯、印度、中国（和南非）。

虚拟交换项目：虚拟交换项目是一种教育实践, 指学习者群体长时间参与在线跨文化互动并与 国际同龄人进行合作。虚拟交换项目需在教育者/项目组织者的指导下, 并被列入学生的教育 计划。虚拟交换项目也被称为远程协作、在线跨文化交流、协作式在线国际学习 (COIL)、国 际在线学习、全球网络学习等。

虚拟流动: 是指高等教育中的学生和教师不离开所在国, 而是以线上方式在另一国家的机构进 行一定时间的学习或教学。它是出国留学等实际流动方式的补充。例如, 虚拟流动在伊拉斯姆 斯项目中的应用。

数字技能：指使用信息技术和互联网查找、评估、利用、共享和创建内容所需的技能。

公正：公平对待虚拟交换项目中的所有相关人员。

在线教学：在线教学是通过互联网进行的教育。它通常被称为线上教学，是远程教育的一种。 在线教学课程可以是同步（实时）的, 也可以是异步（录播）的。 可持续：指在虚拟交换项目可随着时间继续推行而不会造成伤害（例如对环境）或导致其他问 题。 


\section{Appendix B \\ Full list of interview questions (VE example)}

\section{Background information}

- Can you tell us about your role and background?

- How have you met?

- Have you had any previous collaboration before the VE?

\section{Context and details of the VE}

- How did you start/have the idea to set up the VE?

- What did you do as part of the planning stage?

- Can you tell us about the nature and objectives of each course and the overall objectives of the VE?

- How many students were involved at each institution and who were they (PG/UG, areas of study)?

- What was the length and frequency of the exchanges?

- Which tasks and tools were used?

- Have you received any feedback from participants? (formal/informal) Can you tell us a bit more?

\section{Opportunities, challenges and ways forward}

- Overall, were you satisfied with the experience of VE? Which were the main positive aspects?

- Looking back, which were the main challenges that you encountered?

- Has the experience of working with the other institution/colleague made you reflect on your own teaching practice? In what ways?

- Do you think that the VE experience has had an impact on your students (e.g., changes you might have noticed)?

- If you had to do this experience again what would you change?

- How would you like to improve your experience of VE?

- Would you benefit from any support (e.g., further training)? 


\section{Appendix C}

\section{VE Example Background Information}

The VE partnership between TM and NC developed organically, which NC described as "a series of coincidences". NC had travelled to the Chinese institution a number of times for over 10 years prior to meeting TM. These institutionally funded trips were physical mobility activities for academic teaching in China during the summer and for one academic semester during NC's sabbatical leave. As NC and TM casually got to know each other, they discovered that they shared a willingness to create intercultural experiences for their students.

NC: I tried working with internationally with other people. I've tried doing that since 1993 when we first got email on the campus

Following a visit from NC to TM's classroom to introduce international perspectives, NC and TM sought opportunities for a future collaboration in the form of an email exchange for business writing classes in each country. NC had knowledge of VE through a conference and introduced the concept to TM, but neither had received any formal VE training.

Planning for the exchange took place via informal conversations, yet included a clear identification of the objectives and motivation for student participation at both institutions. In China, the aim was to provide English as a Foreign Language (EFL) learners opportunities to develop their English, communication, and writing skill, while in the USA, the aim was to provide college students an intercultural experience and improve motivations for writing.

The instructors ran the VE for the first time in the 2019-20 academic year. They decided to follow an experiential learning approach. They set out to implement the exchange with their initial ideas and improve the design in the subsequent years based on feedback and appraisal of experiences and learning gains.

NC: We didn't formalize anything. I think that the idea was, let's try this and see how it goes. And then think about how we might be able to structure it.

7 students from the American community college and 15 students from the Chinese institution participated in the VE in intercultural groups of 4-6, each group consisting of 3-4 Chinese and 1-2 American students. NC and TM designed a writing task that could be incorporated into the business writing course syllabi at both institutions with Chinese students acting as authors and American students acting as editors for a promotional letter. The topic of promotional letter was selected because both MS and TM thought it would create instances of 'failed' intercultural communication, which could act as critical moments (i.e., opportunities for developing interculturality). 
NC: Promotional letters were ... a good venue for teaching them. ... I mean, intercultural communication gets really interesting, we're at the point when it fails. Right. So that's the moment when you actually learn something about the other culture ... so I was hoping that that would happen, at least that that kind of teachable moment would happen.

The task was not assessed but was introduced as part of the course requirements and assignments. In China, students received some academic recognition for their VE participation. No formal VE assessment and evaluation mechanisms were put in place beyond informal teacher observations and reflections. In the interview, both NC and TM reported positive evaluations of the exchange as regards increased enthusiasm and participation and positive learner comments.

NC: I'm judging their enthusiasm by the, the speed with which they did the assignments compared to the other assignments in the class [...]

TM: I think they several of them said to me in class as well, or they appreciate the opportunity for real life communication and yeah, for many of them is the first time and if not for and the experience, I think, is already valuable and the change.

The first VE iteration was interrupted by the Covid-19 pandemic because the American students had little access to IT outside the classroom. This meant that some students in the US were not able to participate at all or as much as they wished to, while students in China had access to content at least on a smart phone (as reported by YB in Excerpt 6).

NC: This was the big complication, because I had a face to face class I was meeting them and then ... we just went completely online. I didn't have Zoom sessions or WebEx or anything like that.... They were ... baffled for the first couple weeks 